\title{
Selective Culture of Mitotically Active Human Schwann Cells from Adult Sural Nerves
}

\author{
J. Lynn Rutkowski, PhD, ${ }^{*}$ Gihan I. Tennekoon, MD, ${ }^{*}$ and John E. McGillicuddy, MD†
}

\begin{abstract}
We devised a simple method to isolate mitotically active human Schwann cells from sural nerve biopsy specimens and expand the population in culture. Nerve fascicles were treated with cholera toxin for 7 days in culture before dissociation, which increased the cell yield at least twenty-five-fold over immediated tissue dissociation. Digesting the tissue completely with enzymes in serum-containing medium resulted in the highest cell viability, and released 2 to $6 \times 10^{4}$ cells $/ \mathrm{mg}$ of tissue. Seeding the cells on a poly-L-lysine substrate in a small volume of serum-free medium optimized the plating efficiency. Although Schwann cells comprised $90 \%$ of the initial culture population, their numbers declined over time due to a faster mitotic rate of the fibroblasts in the presence of cholera toxin alone. However, treating the cultures with a combination of cholera toxin and forskolin, which act synergistically to elevate cyclic AMP levels, inhibited fibroblast growth without causing Schwann cell toxicity. Adding glial growth factor to the adenyl cyclase activators maximized Schwann cell proliferation, and the population rapidly and selectively expanded. Therefore, it should be possible to generate large numbers of Schwann cells from diseased nerves to study defects in cell function or from normal nerves to study the effects of Schwann cell grafts on neuronal regeneration.
\end{abstract}

Rutkowski JL, Tennekoon Gl, McGillicutdy JE. Selective culture of mitotically atrive human Schwann cells from adult sural nerves. Ann Neurol 1992:31:580-580

Schwann cells, the only glial cells in the peripheral nervous system (PNS), support neuronal function in several different ways. The myelin sheath produced by Schwann cells permits the rapid transmission of nerve impulses via saltatory conduction at the nodes of Ranvier [1]. A class of peripheral neuropathices distinguished by segmental demyelination and slowed conduction velocity is believed to result from defects in Schwann cell metabolism [2]. These neuropathies can be either inherited or acquired, yet little is known about their pathogenesis. The ability to generate large numbers of human Schwann cells from biopsy specimens may help to identify the cellular mechanism involved in some of these demyelinating diseases.

In addition to facilitating nerve conduction, Schwann cells enable neurons to regenerate after injury. By secreting neurotrophic factors, they aid neuronal survival and stimulate axonal sprouting [3-5], and by expressing adhesion molecules on their cell surface $\{6-8\}$, Schwann cells guide regenerating axons through the remaining basal lamina tubes back to their synaptic contacts $[\%, 10]$. Transplanting peripheral nerves into the central nervous system demonstrated that Schwann cells also permit central axons to regenerate [1]\}, and Schwann cell implants are now being explored as a means to facilitate recovery in animal molets of Parkinson's disease [12], and peripheral nerve $[13-15]$ and spinal cord injury $[16-18]$. The results from animal experiments appear promising, but cescing the pocential benefirs of these therapeuric approaches in humans would require large numbers of Schwann cells

Human Schwann cells have been cultured from adult nerves by successive recxplantarion, allowing the Schwann cells to slowly migrate out from the antaked explant over several weeks in culture [19-22]. However, without the addition of mitogens to the cultures, few of the cells divided, and the vields obtained with this time-consuming technigue were very low $[20]$. Therefore, we devised a mothod to ssolate mitotically active Schwann cells from human nerves and to expand the population in culture with agents selected to stimulate Schwann cel! proliferation while inhibiting noroblast growth.
Materials and Methods
Cell Isolation
Normal human sural nerve specinens were obtancel from patients ranging from 18 to al) years ohd who underwent graft repair of a brachial plexus injary. Nerve fascickes were dissected from the epincurtum and werghed, and 10 mar of

From the Departments of "Pediatrics, *Neurology, and + Neurosurgery, Universicy of Michigan. Am Arbor, MI.

Received Sep 27, 1901. Accepted for publication Nov 22, 1991.
Address correspondence to Dr Rutkowski, Ituversity of Mi higan,


MI $48109-0570$ 
tissue/ $\mathrm{ml}$ of feeding medium (FM) was incubated in plastic dishes for 0 to 14 days in humidified $10 \%$ carbon dioxide at $37^{\circ} \mathrm{C}$. The FM consisted of Dulbecco's modified Eagle's medium containing $4.5 \mathrm{gm} /$ liter of glucose and supplemented with $10 \%$ heat-activated fetal bovine serum and $0.1 \mu \mathrm{g} / \mathrm{ml}$ of cholera toxin (Sigma, St. Louis, MO). The tissue was then dissociated with 80 units $/ \mathrm{ml}$ of collagenase and 0.8 unit $/ \mathrm{ml}$ of dispase (Boehringer Mannheim, Indianapolis, IN) in the FM. Approximately $20 \mathrm{mg}$ of tissue/ $\mathrm{ml}$ of enzyme solution was placed in a capped rube, gassed with $10 \%$ carbon dioxide, and rocked gently for 18 hours at $37^{\circ} \mathrm{C}$. After complete enzymatic digestion, the cells were washed twice with $\mathrm{Ca}^{2+}$. and $\mathrm{Mg}^{2+}$-free phosphate-buffered saline solution (PBS) containing $0.04 \%$ ethylenediaminetetraacetic acid (EDTA), washed once with $\mathrm{S} 4$ serum-free medium [23], and then resuspended in $\mathrm{S} 4$.

To determine cell viability, an aliquot of the cell suspension was stained in $100 \mu \mathrm{M}$ propidium iodide, and then counted in a hemocytometer under a Leitz microscope (Wetzlar, Germany) equipped with epifluorescence. This dye penetrates the membrane of only dead or dying cells and binds to nucleic acids, causing the cell nuclei to fluoresce red when excited at $490 \mathrm{~nm}$. A second aliquot was treated with $50 \%$ ethanol to render all cells permeable to the dye, and the total number was counted. The cell suspension was diluted to 4 to $5 \times 10^{5}$ cells $/ \mathrm{ml}$ of $\mathrm{S} 4$ medium, and $1 \mathrm{ml}$ was spread on $10-\mathrm{cm}$ plastic dishes coated with $100 \mu \mathrm{g} / \mathrm{ml}$ of poly-Llysine ( $\mathrm{MW}>300,000$, Sigma). Nine milliliters of the FM was added 18 hours after seeding. Plating efficiency was determined by counting the number of both attached and unattached cells 48 hours after seeding. Cells were subcultured when confluent onto poly-i-lysine-coated dishes.

\section{Immunofluorescent Staining}

The antibodies and their dilutions used to distinguish between Schwann cells and fibroblasts were as follows: antihuman nerve growth factor (NGF) receptor (HB 8737 , American Tissue Culture Collection, Rockville, MD), tissue culture supernatant; anti-bovine S-100 protein (IgG fraction, Dakopatts, Carpinteria, (A), 1:100; anti-bovine galactocerebroside (lgG fraction, Advanced Immunochemicals, Long Beach, CA), 1:500; anti-human glial fibrillary acid protein (IgG fraction, Chemicon, Temecula, CA), 1: 100; anti-human laminin (purified $\operatorname{lgG}$, Boehringer Mannheim), $1: 20$; anti-human fibronectin (purified IgG, Boehringer Mannheim), 1:20; anti-human Thy-1 (gift from Dr Wolfgang Rettig, University of Virginia), tissue culture supernatant [24].

For indirect immunofluorescent staining, cells were seeded on glass coverslips coated with $1 \mu \mathrm{g} / \mathrm{ml}$ of poly-L-lysine. Surface antigens were localized after fixation with $4 \%$ formaldehyde in complete Dulbecco's PBS for 10 minutes at $23^{\circ} \mathrm{C}$. To localize intracellular antigens, cells were additionally treated with ethanol for 5 minutes at $-20^{\circ} \mathrm{C}$. Coverslips were incubated with primary antibodies diluted in medium containing $10 \%$ serum for 30 minutes at $37^{\circ} \mathrm{C}$, washed in three changes of medium, and then incubated with the appropriate fluorescein-conjugated antiimmunoglobulin antibody (affinity purified, Organon Tenika-Cappell), diluted 1:400. After washing and postixation in $95 \%$ ethanol and $5 \%$ acetic acid, the coverslips were mounted in AF-1 (Citifluor, London, UK) containing $2 \mu \mathrm{M}$ Hoechst 33342 and examined with a Leitz fluorescent microscope. Cell number per visual field was determined by counting Hoechst-stained nuclei under ultraviolet (UV) light.

\section{Mitotic Activity}

Approximately 1-mm slices of some nerve explants were removed before enzymatic digestion and incubated in $30 \mu \mathrm{M}$ bromodeoxyuridine (BrdU) for 18 hours. The tissue was fixed in methanol for 15 minutes at $4^{\circ} \mathrm{C}$, and the DNA was denatured in $2 \mathrm{~N}$ hydrochloric acid ( $\mathrm{HCl}$ ) for 1 hour. After neutralization with $0.1 \mathrm{M}$ sodium borate ( $\mathrm{pH} 9$ ), the tissue was incubated for 1 hour with fluorescein-conjugated antiBrdU (Boehringer Mannheim, 1:5 dilution), and then washed and mounted.

Cells were seeded on glass coverslips and grown in medium containing various Schwann cell mitogens in addition to cholera toxin, including forskolin (Sigma), glial growth factor (GGF) prepared by carboxymethyl cellulose chromatography [25], or $60 \mu \mathrm{g} / \mathrm{ml}$ of bovine axolemma and myelin (provided by Dr Jun Yoshino, Colgate University) [26, 27]. After 48 hours, BrdU was added to a final concentration of $30 \mu \mathrm{M}$, and the cells were fixed 18 hours later. Cells were first stained for S-100, and the antigen-antibody complex was cross-linked for 30 minutes with $0.5 \%$ carbodiimide in PBS. Coverslips were then processed for BrdU staining.

The proportion of Schwann cells in the S phase was determined by counting the number of cells double-labeled for S-100 and BrdU out of the total S-100-positive population. S-100-negative cells were assumed to be fibroblasts; thus, S-100-negative, BrdU-positive cells were scored as mitotic fibroblasts. The total number of fibroblasts was estimated by subtracting the number of S-100-positive cells from the total number of cells.

\section{Expansion of Schwann Cell Cultures}

Sural nerves were dissociated as described, and the cells were allowed to attach and spread for 2 days. The cultures were then treated with either 0.1 to $1.0 \mu \mathrm{g} / \mathrm{ml}$ of cholera toxin, 1 to $10 \mu \mathrm{M}$ forskolin, or various concentrations of cholera toxin and forskolin combined. Additional cultures were treated with a combination of adenylate cyclase activators plus $5 \mu \mathrm{g} / \mathrm{ml}$ of GGF. When the cultures reached confluence, the cells wete seeded onto coverslips, and the Schwann cells and fibroblasts were identified morphologically or by indirect immunofluorescent staining. The effect of each treatment was evaluated for at least three passages.

\section{Results \\ Cell Isolation}

Immediately dissociating human sural nerve specimens released 700 to 800 viable cells $/ \mathrm{mg}$ of tissue. In addition, the plating efficiency was low and the Schwann cells appeared to remain quiescent or had such a delayed response to mitogens that fibroblasts overgrew the cultures (not shown). However, maintaining the nerve in explant culture for 7 days in the presence of cholera toxin increased the cell yield at least twenty- 




A



Fig 1. Isolation of cells from sural nerve specimens. Nerve explants were treated for 7 days in culture with $0.1 \mu \mathrm{g} / \mathrm{ml}$ of cholera toxin before enzymatic dissociation. (A) Bromodeoxyuridine labeling for 18 bours before dissociation showed that cells were dividing within the explants $1 \times 102$ before $31 \%$ reduction). (B) Phase micrograph of a live primary culture 4 days after plating $(\times 205$ before $30 \%$ reduction). Most cells displayed the characteristic bipolar morphology of Schwann cells.

five-fold. The Schwann cells began to divide within the explant by 3 days in vitro but their mitotic activity reached a plateau between 7 and 10 days (Fig $1 \mathrm{~A}$ ).

Approximately $85 \%$ of the cells remained viable after the cell isolation procedure, which consistently yielded 2 to $6 \times 10^{4}$ cells/mg of nerve. Removing serum from the medium during seeding was found to increase attachment by approximately $30 \%$, and reducing the volume, which increases the rate of attachment, improved the plating efficiency further. Attachment to various substrates including plastic, laminin, fibronectin, type I collagen, extracellular matrix from endothelial cells $[28]$ or EHS sarcoma cells (Matrigel, Collaborative Research, Bedford, MA), and poly-L-lysine was tested. Attachment to poly-L-iysine was found to be superior (data not shown). A maximal plating efficiency of $85 \%$ was achieved by seeding in $1 \mathrm{ml}$ of serum-free medium onto poly-L-lysine.
After attachment, the cultures were maintained in serum-containing medium supplemented with cholera toxin to stimulate Schwann cell growth. Four days after plating, most cells displayed the bipolar morphology typical of primary rat Schwann cells, and many contained phase-bright, cytoplasmic inclusions of myelin fragments, as shown in Figure 1B.

\section{Immunofluorescent Staining}

Human Schwann cells were identified after 4 days in culture by their positive staining for galactocerebroside, S-100, and the NGF receptor (Fig 2A-C). By 12 days in culture, galactocerebroside staining was not detected, but staining for S-100 and the NGF receptor persisted for at least eight passages (39) days). The matrix molecules, laminin and fibronectin, were found on the surface of Schwann cells and fibroblasts, respectively (not shown). However, distinguishing Schwann cells from fibroblasts was difficult because of the punctated staining pattern. Moreover, fibronectin may not be a reliable fibroblast marker because it has been detected on the surface of some rat Schwann cells in culture by double-staining [29]. We found that human fibroblasts were more easily identified with an antibody to the surface Thy-1 antigen (Fig 2D).

S-100-positive staining was then used to determine the percentage of Schwann cells in the total cell population after various times in culture. In primary cultures at day 4, 90\% of the cells were S-100 positive (Fig 3). Schwann cells still predominated at day 12 after two passages, but after this point, the percentage of fibroblasts markedly increased. After eight passages at day 39 , only $27 \%$ of the population was comprised of Schwann cells.

\section{Response to Mitogens}

In a mixed population of Schwann cells and fibroblasts, it was difficult to determine which cell type was responding based on morphology and $\mathrm{BrdU}$ labeling alone. Therefore, the cultures were double-stained for S-100 to identify Schwann cells and for BrdU to identify mitotic cells (Fig 4A, B). The response of the two cell populations to various mitogens is shown in the Table.

Since Schwann cells could not be maintained in culture without the use of mitogens, cholera toxin was always included in the medium. When treated with cholera toxin alone, $28 \%$ of the Schwann cells and $43 \%$ of the fibroblasts entered the S phase of the cell cycle during the 18-hour labeling period. The mitotic activity of the Schwann cells was increased further, without affecting the mitotic rate of the fibroblasts, by combining cholera toxin with either axonal membrane fragments or GGF. The addition of myelin fragments did alter the mitotic rate of either cell type. However, the combination of cholera toxin, forskolin, and GGF 


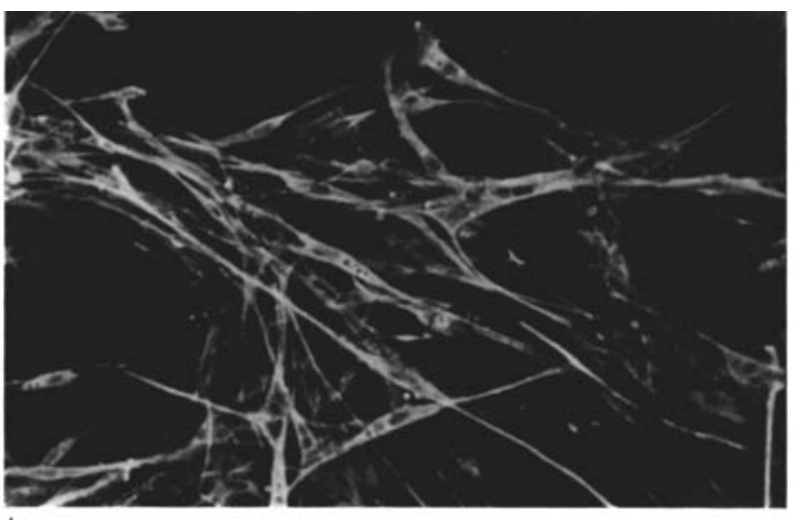

A

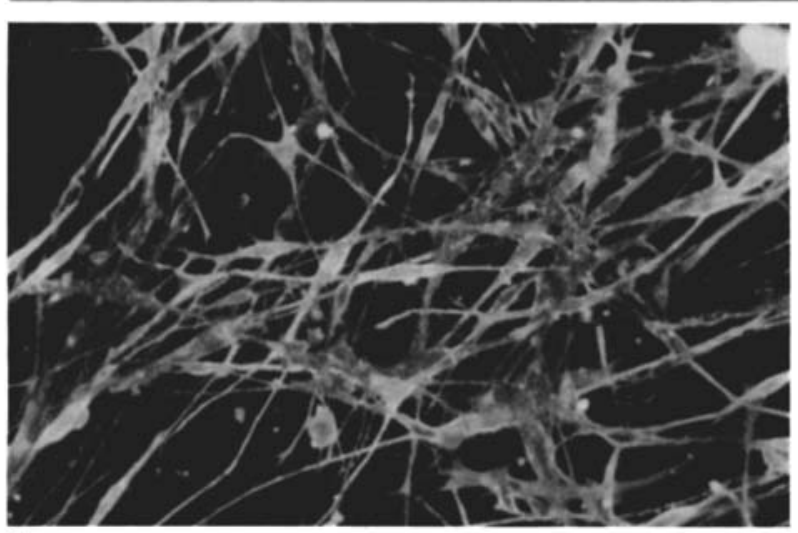
C


Fig 2. Identification of cell types in culture. Scbwann cells were identified by indirect immunofuorescent staining. Staining for (A) galactocerebroside, (B) nerve growth factor (NGF) receptors. and (C) S-100 was evident at day 4 (primary culture). Galactocerebroside was no longer detectable at day 12, but staining for NGF receptors and $S-100$ persisted for at least 39 days. (D) By day 18, the number of fibroblasts detected by staining for the Thy- 1 antigen bad markedly increased. $(A-D, \times 205$ before $31 \%$ reduction.)

stimulated the mitotic rate of the Schwann cells to $45 \%$ while reducing that of the fibroblasts to $9 \%$.

\section{Expansion of Schwann Cell Cultures}

Activators of adenyl cyclase such as cholera toxin and forskolin reportedly have opposite effects on the proliferation of Schwann cells and fibroblasts $[30,31]$. We found that the fibroblasts continued to proliferate when treated with up to $1 \mu \mathrm{g} / \mathrm{ml}$ of cholera toxin. Cholera toxin receptors (GM1 ganglioside) are concentrated in Schwann cell membranes [32, 33], and we found most of the bound toxin associated with Schwann cells by immunofluorescent staining (not shown). Forskolin, at $10 \mu \mathrm{M}$, blocked fibroblast growth but this concentration was toxic to human Schwann cells. However, $0.1 \mu \mathrm{g} / \mathrm{ml}$ of cholera toxin plus $1 \mu \mathrm{M}$ forskolin inhibited fibroblast growth without adversely affecting the Schwann cells. The addition



Fig 3. Decline of the Schuann cell population over time. Cells were seeded onto coverslips at each passage (p), and the Scbwann cells were identified by S-100-positive staining. The total cell number was determined by nuclear staining with Hoechst dye 33342. Values represent the mean of four to eight fields \pm standard error of mean, and over 200 cells/time point were counted. 

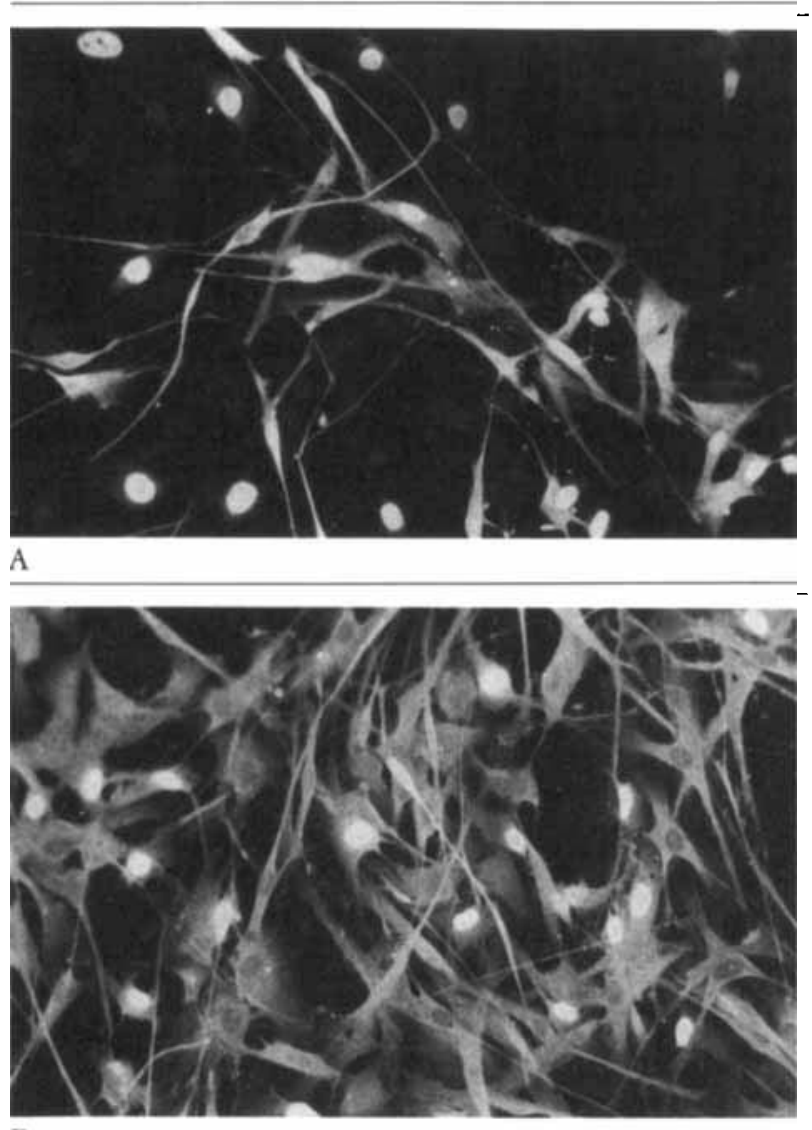

B

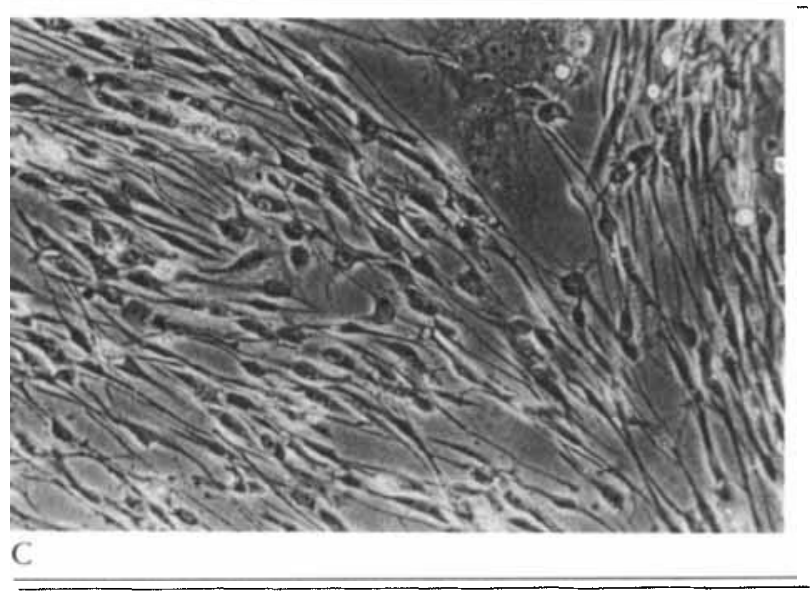

Fig 4. Selective expansion of the Sibuann iell population. Cells were double-labeled for $S-100$ (stains the Schuann cell cytoplasm) and bromodeoxyuridine (stains the nucleus of cells in the S phase). (A) Culutres uere maintained for three passages on cholera toxin alone. Fibroblasts eventually overgrew the cultures because they divided faster than Scbwann cells. (B) Cultures were maintained for three passages on a combination of cholera toxin. forskolin, and glial grouth factor. Schuann cells proliferated rapidly while fibroblast grouth was inhibited, and the number of fibroblasts decreased with each pasiage. (C) Schwann cells comprised $98 \%$ of the cultures, as shoun by phase microscopy. (A-C. $\times 205$ before $31 \%$ reduction.) of $5 \mu \mathrm{g} / \mathrm{ml}$ of GGF to this combination of adenyl cyclase activators resulted in the rapid and selective proliferation of Schwann cells, and the fibroblasts were diluted out with each subculture (see Table; Fig 4A, B). Cultures highly enriched in Schwann cells (98\%) were obtained after three passages (Fig 4C).

\section{Discussion}

The objective of this study was to maximize the recovery of adult human Schwann cells from peripheral nerve specimens and to optimize their mitotic activity in culture. We devised a rapid, simple, and effective method incorporating standard techniques, and discuss the most crucial aspects of the procedure below. First, removing the nerve fascicles from the epineurial sheath eliminated one source of contaminating fibroblasts. Second, preculturing the nerve fascicles in the presence of cholera toxin for 7 days before dissociation increased the cell yield fivefold. Degenerating the axonal and myelin membranes within the explant stim. ulated Schwann cell proliferation [34-36], which was augmented by activating the cyclic AMP pathway with cholera toxin $\{37,38\}$. Third, the tissue was completely digested with enzymes in serum-containing medium to maintain the highest viability. Finally, optimal plating efficiency was achieved by seeding the cells on a polyL-lysine substrate in a small volume of serum-free medium.

Human Schwann cells were previously cultured from adult nerve specimens by successive rexplantation [19-22], but the yields obtained with this technique were very low. High yields of either rat $\{39]$ or human Schwann cells $[40]$ were obtained by enzymatic dissociation with fetal and newborn tissues, which have a higher cell density and less connective tissue. However, only 600 cells/mg were obrained from adult rat nerves by enzymatic digestion [30], and we initially obtained similar cell yields from adult human nerves. However, preculturing the explant in the presence of cholera toxin stimulated the Schwann cells to detach from their myelin sheaths and undergo mitosis, which dramatically increased the cell yield. A 2-cm sural nerve biopsy specimen $100 \mathrm{mg}$ of nerve) produced about $2 \times 10^{6}$ Schwann cells, and their number continued to expand in culture.

The cell composition of the cultures was determined over time by staining with antiboties to cell-specific antigens. We found that like rat Schwann cells in culture, human Schwann celis transiently expressed galactocerebroside $[41,42]$ yet continued to express $S-100$ protein, NGF receptors, and laminin in long-term cultures as previously reported $[40,43,44]$. Schwann cells comprised at least $90 \%$ of the initial culture population, and many mitotic human Schwann cells were detected. However, the proportion of fibroblasts increased with each subculture because in the presence 


\begin{tabular}{|c|c|c|}
\hline \multirow[b]{2}{*}{ Treatment } & \multicolumn{2}{|c|}{ Nuclear Incorporation of BrdU } \\
\hline & Schwann Cells $(\%)$ & Fibroblasts (\%) \\
\hline Cholera toxin $(0.1 \mu \mathrm{g} / \mathrm{ml})$ & $28 \pm 1.0$ & $43 \pm 2.4$ \\
\hline Cholera toxin + myelin $(60 \mu \mathrm{g} / \mathrm{ml})$ & $30 \pm 0.9$ & $51 \pm 1.9$ \\
\hline Cholera toxin + axolemma $(60 \mu \mathrm{g} / \mathrm{ml})$ & $36 \pm 1.3^{b}$ & $46 \pm 1.7$ \\
\hline Cholera toxin + GGF $(5 \mu \mathrm{g} / \mathrm{ml})$ & $37 \pm 1.9^{b}$ & $35 \pm 1.2$ \\
\hline Cholera toxin + GGF + forskolin $(1 \mu \mathrm{M})$ & $45 \pm 3.2^{b}$ & $9 \pm 0.7^{b}$ \\
\hline
\end{tabular}


Schwann celis and fibroblasts was determined by doubie-staining for S-100 and BrdU, as depicted in Fig 4A and B. Over 400 cells in each treatment group were counted. Values represent the mean of $4-8$ fields \pm SEM.

'Significantly different from cholera toxin alone ( $p>0.01$, Student's $t$ test).

$\mathrm{BrdU}=$ bromodeoxyuridine; $\mathrm{GGF}=$ glial growth factor.

of cholera toxin alone, their rate of proliferation was faster than that of the Schwann cells. Adding a second mitogen for human Schwann cells, either GGF or axolemma $[20,45]$, increased the mitotic rate of the Schwann cells to approximately that of the fibroblasts.

These results suggest that it may be possible to maintain cultures highly enriched in human Schwann cells by treatment with a combination of mitogens immediately after isolation. Moreover, activation of adenyl $c y$ clase, which stimulates Schwann cell mitosis [30], has blocked the response of fibroblasts to growth factors [31]. We found that cholera toxin and low concentrations of forskolin, which act synergistically to elevate cyclic AMP levels [46], were required to inhibit fibroblast growth without causing Schwann cell toxicity. Adding GGF to the adenyl cyclase activators potentiated the growth rate of the human Schwann cells, as has been shown for rat Schwann cells [38, 47], and virtually pure cultures were obtained within a few passages. However, this combination of mitogens could prove to be problematic since prolonged treatment has led to the transformation of rodent Schwann cells [48], which formed tumors when injected back into nerves [49].

Although human Schwann cells can be isolated from fetal $[40,43,44]$ and autopsy tissue [45], the ability to generate large numbers of Schwann cells from biopsy specimens would offer unique advantages. With our procedure, relatively large numbers of Schwann cells can be obtained from a sural nerve biopsy specimen within a few weeks. Therefore, it may soon be possible to study biochemical defects in patients with demyelinating neuropathies of genetic or unknown causes while the patient is still living. Also, if human Schwann cell cultures can be expanded without transformation or loss of their functional properties, it may be possible to transplant autologous Schwann cells for clinical experimentation, thus eliminating autoimmune-mediated graft rejection.
This work was supported by grants from the National Institutes of Health (NS 21700 and NS 22849) and from the Johns Hopkins University Center for Alternatives to Animal Testing.

We thank Dr James Campbell for providing nerve tissue at the initial stage of the project, Drs David Cornblath and Guy McKhann for their helpful discussions, Yan Feng for technical assistance, and Susan Babbitt for editorial assistance.

\section{References}

1. Ritchie JM. Physiological basis of conduction in myelinated nerve fibers. In: Morell P, ed. Myelin. New York: Plenum Press, 1984:117-122

2. Dyck PJ, Karnes J, Lais A, et al. Pathologic alterations of the peripheral nervous system in humans. In: Dyck PJ, Thomas PK, Lambert EH, Bunge R, eds. Peripheral neuropathy. Philadelphia: WB Saunders, 1984:857-860

3. Heumann R, Korsching S, Bandtlow C, Thoenen $\mathrm{H}$. Changes of nerve growth factor synthesis in nonneuronal cells in response to sciatic nerve transection. J Cell Biol 1987;104: $1623-1631$

4. Bosch EP, Zhong W, Lim R. Axonal signals regulate expression of glia maturation factor-beta in Schwann cells: an immunohistochemical study of injured sciatic nerves and cultured Schwann cells. J Neurosci 1989;9:3690-3698

5. Muir D, Gennrich C, Varon S, Manthorpe M. Rat sciatic nerve Schwann cell microcultures: responses to mitogens and production of trophic and neurite-promoting factors. Neurochem Res 1989;14:1003-1012

6. Rieger F, Nicolet M, Pinçon-Raymond $M$, et al. Distribution and role in regeneration of N-CAM in the basal laminae of muscle and Schwann cells. J Cell Biol 1988;107:707-719

7. Seitheimer B, Schachner M. Studies of adhesion molecules mediating interactions between cells of peripheral nervous system indicate a major role for $\mathrm{Ll}$ in mediating sensory neuron growth on Schwann cells in cultures. J Cell Biol 1988;107:341-351

8. Bixby JL, Lilien J, Reichardt LF. Identification of the major proteins that promote neuronal process outgrowth on Schwann cells in vitro. J Cell Biol 1988;107:353-361

9. Bennett MR, McLachlan EM, Taylor RS. The formation of synapses in reinnervated mammalian striated muscle. J Physiol 1973;233:481-500

10. Sadinsky D, Pepe FA, Liu CN. The neurolemma cell in peripheral nerve degeneration and regeneration. Exp Neurol 1964;9: $441-451$ 
11. Aguayo AJ. Axonal regeneration from injured neurons in the adult mammalian central nervous system. In: Cotman CW, ed. Synaptic plasticity. New York: Guilford Press, 1985:457-484

12. Kordower JH, Fiandaca MS, Notter MFD, et al. NGF-like trophic support from peripheral nerve for grafted rhesus adrenal chromaffin cells. J Neurosurg 1990;73:418-428

13. Zalewski AA, Azzam NA, Williams LR. Do axon-free nerves lead to the formation of Schwann cell-cables within silicone chambers? Soc Neurosci Abstr 1990;16:1282

14. Daniloff JK, Kim D, Smith A, et al. Transplanted Schwann cell (SC) cultures support regeneration in severed nerves. Soc Neurosci Abstr 1990;16:37

15. Knoops B, Hurtado $H$, van den Bosch de Aguilar P. Rat sciatic nerve regeneration within an acrylic semipermeable tube and comparison with a silicone impermeable material. I Neuropathol Exp Neurol 1990;49:438-448

16. Paino CL, Bunge MB. Axon growth into implants of Schwann celis placed in lesioned spinal cord. Soc Neurosci Abstr 1990; 16:128?

17. Pulford BE, Mihajilov AR, Whalen LR, Nornes HO. Effects of cultured adrenal chromaffin and Schwann cell implants on hindlimb reflexes of the 6-OHDA lesioned spinal rat. Soc Neurosci Abstr 1990;16:37

18. Cohen RW, Goodglick T, Kromer LF. Immunocytochemical characterization of CNS axonal regeneration through transplants of Schwann cell/matrix cables. Soc Neurosci Abstr 1990;16: 1282

19. Askanas V, Engel WK, Dalakas MC, et al. Human Schwann cells in tissue culture: histochemical and ultrastructural studies. Neurology 1980;37:329-337

20. Sobue $G$, Brown MJ, Kim SU, Pleasure D. Axolemma is a mitogen for human Schwann cells. Ann Neurol 1984;15:449452

21. Scarpini E, Meola G, Baron P, et al S- 100 protein and laminin: immunocytochemical markers for human Schwann cells. Exp Neurol 1986;93:77-83

22. Scarpini $\mathrm{E}$, Ross AH, Rosen JL, et al. Expression of nerve growth factor receptor during human peripheral nerve development. Dev Biol 1988;125:301-310

23. Needham LK, Tennekoon GI, McKhann GM. Selective growth of rat Schwann cells in neuron- and serum-free primary culture. J Neurosci 1987;7:1-9

24. Rettig WJ, Nishimura $H$, Yenamandra AK, et al. Differential expression of the Thy- 1 gene in rodent-human somatic cell hybrids. I Immunol 1987;138:4484-4489

25. Brockes JP, Lemke GE, Balzer DR Jr. Purification and preliminary characterization of a glial growth factor from the bovine pituitary. J Biol Chem 1980;255:8374-8377

26. DeVries GH, Anderson MG, Johnson D. Fractionation of isolated rat CNS myelinated axons by sucrose density gradient centrifugation in a zonal rotor. J Neurochem 1983;40:17091717

27. Yoshino JE, Dinneen MP, Lewis BL, et al. Differential proliferative responses of cultured Schwann cells to axolemma- and myclin-enriched fractions. I. Biochemical studies. J Cell Biol $1984 ; 9): 23(\%)-2313$

28. Gospodarowicz D, Greenburg G, Foidart JM, Savion N. The production and iocalization of laminin in cultured vascular and corneal endothelial cells. J Cell Physiol 1981;107:171-183

29. Scarpini E, Kreider BQ, Lisak RP, Pleasure DE. Establishment of Schwann cell cultures from adult rat peripheral nerves. Exp Neurol 1988;102:167-176

30. Raff MC, Hornby-Smith A, Brockes JP. Cyclic AMP as a mito- genic signal for cultured rat Schwann cells. Nature $1978 ; 273$ $672-673$

31. Heldin N-E, Paulsson Y, Forsberg K, et al. Induction of cyclic AMP synthesis by forskolin is followed by a reduction in the expression of $\mathrm{c}-m y c$ messenger RNA and inhibition of ${ }^{3} \mathrm{H}$-thymidine incorporation in human fibroblasts. I Cell Physiol 1989 138:17-23

32. Spiegel $S$. Fluorescent derivatives of ganglioside $G_{M I}$ function as receptors for cholera toxin. Biochemistry 1985;24:5947-5952

33. Ganser AL, Kirschner DA, Willinger M. Ganglioside localization on myelinated nerve fibres by cholera toxin binding. I Neurocytol 1983;12:921-938

34. Salzer JL, Bunge RP. Studies of Schwann cell proliferation. I. An analysis in tissue culture of proliferation during development, wallerian degeneration, and direct injury. I CAll Biol 1980;84: $739-752$

35. Salzer JL, Williams AK, Glaser L, Bunge RP. Studies of Schwann cell proliferation. 1I. Characterization of the stimulation and specificity of the response to a neurite membrane fraction. Cell Biol 1980;84:753-766

36. Yoshino JE, Griffin JW, DeVries GH. Identification of an axolemma-enriched fraction from peripheral nerve. I Neurochem 1983;41:1126-1130

37. Cassel D, Pfeuffer T. Mechanism of cholera toxin action: covalent modification of the guanyl nucleotide-binding protein of the adenylate cyclase system. Proc Natl Acad Sci USA 1978 75:2669-2673

38. Raff MC, Abney E, Brockes JP, Hornby-Smith A. Schwann cell growth factors. Cell 1978;15:813-822

39. Ratner N, Glaser L, Bunge RP. PC12 cells as a source of neurite-derived cell surface mitogen, which stimulates Schwann cell division. J Cell Biol 1984,98:1150-1155

40. Scarpini E, Kreider BQ, Lisak RP, et al. Cultures of human Schwann cells isolated from fetal nerves. Brain Res 1988.440 $261-266$

41. Mirsky R, Winter J, Abney ER, et al. Myelin-specific proteins and glycolipids in rat Schwann cells and oligodendrocytes in culture. J Cell Biol 1980;84:483-494

42. Rutkowski L, Needham L, Frayer K, et al. Evidence that secondary rat Schwann cells in culcure maintain their differentiated phenotype. J Neurochem 1990;54:1895-1904

43. Kim SU, Yong VW, Watabe $\mathrm{K}$, Shin DH. Human fetal Schwann cells in culture: phenotypic expressions and proliferative capability. J Neurosci Res 1989;22:50-59

44. Assouline JG, Pantazis NJ. Detection of a nerve growth factor receptor on fetal human Schwann cells in culrure: absence of the receptor on fetal human astrocytes. Dev Brain Res 1989; 45:1-14

45. Moretto G, Kim SU, Shin DH, et al. Long-term cultures of human adult Schwann cells isolated from autopsy materials. Acta Neuropathol (Berl) 1984;64:15-21

46. Barovsky K, Brooker G. Forskolin potentiation of cholera toxin-stimulated cyclic AMP accumulation in intact $\mathrm{C} 6-2 \mathrm{~B}$ cells Evidence of enhanced Gs-C coupling. Mol Pharmacol 1985:28 502-507

47. Porter S, Clark MB, Glaser I, Bunge RP. Schwann cells stimulated to proliferate in the absence of neurons retain full functional capability. J Neurosci 1986;6:3070-3078

48. Porter S, Glaser L, Bunge RP. Release of autocrine growth factor by primary and immortalized Schwann cells. Proc Natl Acad Sci USA 1987;84:7768-7772

49. Langford LA, Porter S, Bunge RP. Immortalized rat Schwann cells produce tumours in wiv. J Neurocytol 1988:17:521-529 